\title{
Characteristics and In-Hospital Clinical Outcomes of the Patients Undergoing Carotid Artery Stenting: A single Center Experience
}

Karotis Arter Stentlemesi Uygulanan Hastaların Özellikleri ve Hastane İçi Klinik Sonuçları:

Tek Merkez Deneyimi

\section{İbrahim Kocayiğit, Yusuf Can, Harun Kılıç}

Department of Cardiology, Sakarya University School of Medicine, Sakarya, Turkey

Yazısma Adresi / Correspondence:

İbrahim Kocayiğit

Sakarya University Education and Research Hospital, Department of Cardiology, Sakarya, Turkey 54100

$$
\text { T: }+905309323075 \quad \text { E-mail : ikocayigit@gmail.com }
$$

Geliş Tarihi / Received : 14.04.2021 Kabul Tarihi / Accepte: 04.12.2021

Orcid :

İbrahim Kocayiğit https://orcid.org/0000-0001-8295-9837

Yusuf Can https://orcid.org/0000-0002-4535-7367

Harun Kiliç https://orcid.org/0000-0002-1358-5015

(Sakarya Tip Dergisi / Sakarya Med J 2021, 11(4):737-742) DOI: 10.31832/smj.913188

\footnotetext{
Abstract

Objective The aim of our study was to evaluate carotid artery stenting (CAS) procedures and in-hospital outcomes performed in our instutition.

Materials A total of 86 patients who underwent CAS between January 2019 and December 2019 were analyzed retrospectively. and Methods

Results Among these patients, 46 of the patients (53.5\%) were symptomatic because of a history of transient ischemic attack (TIA) or stroke in the preceding 6 months, and the remain of the patients were asymptomatic (40 patients, $46.5 \%$ ). The mean age of the patients was significantly lower in symptomatic group compared to asymptomatic group $(65.5 \pm 10.7$ vs $70.2 \pm 6.8, \mathrm{p}=0.019)$. Predilatation was performed in 79 patients $(91.9 \%)$. In 7 patients $(8.1 \%)$ postdilatation was required due to insufficient opening. Only in 4 patient, both predilatation and postdilatation was performed during the procedure. In most of the patients (84 patients, 97.7\%) distal embolic protection device (EPD) were used. Only in two patients (2.3\%) proximal EPD were used. Technical success rate was $98.8 \%(85 / 86)$. In-hospital death and disabling stroke was not observed in any patients. TIA was observed in two patients.

Conclusion CAS is safe and effective treatment method in carotid artery stenosis with low complication rates in experienced centers. CAS is alternative treatment to carotid endarterectomy (CEA) especially in patients with high surgical risk.

Keywords acute ischemic stroke; carotid artery stenting; carotid artery stenosis

$\ddot{\mathrm{O} z}$

Amaç Çalı̧mamızın amacı, hastanemizde uygulanan karotis arter stentleme (KAS) prosedürlerini ve hastane içi sonuçları değerlendirmektir.

Gereçve Ocak 2019 ile Aralı 2019 arasinda KAS uygulanan 86 hasta retrospektif olarak incelendi.

Yontemle

Bu hastalardan 46 'stnın (\% 53,5) son 6 ay içinde geçici iskemik atak veya inme öyküsü mevcuttu. Hastaların ortalama yaşı semptomatik grupta, asemptomatik gruba göre anlamlı olarak daha düsüktü $(65,5+10,7$ vs $70,2 \pm 6,8, p=0,019)$. Predilatasyon 79 hastaya $(\% 91,9)$ yapılmıst. Yedi hastada (\% 8.1) yetersiz açılmaya bağh olarak postdilatasyon gerektiği görüldü. Sadece 4 hastada işlem sırasında hem predilatasyon hem de postdilatasyon yapılmıştı. Hastaların çoğunda ( 84 hasta,\% 97,7) distal embolik koruma cihazı kullanıldı. Sadece iki hastada (\% 2.3) proksimal emboli koruma cihazı kullanıldı. Teknik başarı oranı\% 98,8 (85/86) idi. Hastane içi ölüm ve kalıcı inme hiçbir hastada görülmedi. İki hastada geçici iskemik atak görüldü.

Sonuç KAS, deneyimli merkezlerde düşük komplikasyon oranlarn ile karotis arter darlyğında güvenli ve etkili bir tedavi yöntemidir. KAS, özellikle cerrahi riski yüksek hastalarda karotis endarterektomiye alternatif bir tedavidir. 


\section{INTRODUCTION}

Stroke is one of the most important cause of death and functional disability worldwide. ${ }^{1}$ The majority of all strokes are ischemic in origin, accounting for over $87 \%$ of all strokes. ${ }^{2}$ Approximately $15 \%$ of ischemic strokes originate from atherosclerotic internal carotid artery (ICA) stenosis. ${ }^{3}$ Although carotid endarterectomy (CEA) is the gold standard for the treatment of carotid stenosis, carotid artery stenting (CAS) is increasingly and widely being used as a promising treatment method especially in patients with high surgical risk.

Carotid stenosis is defined as symptomatic if associated with symptoms in the preceding 6 months and asymptomatic if no prior symptoms can be identified or when symptoms occurred $>6$ months ago. ${ }^{4}$ According to the recent guidelines, carotid artery revascularization is advised with a Class 2a recommendation in patients with asymptomatic carotid artery stenosis of $>60 \%$, and a Class 1 indication in patients with symptomatic carotid artery stenosis of $>50 \% .4$ The treatment modality should be chosen considering the comorbid conditions, anatomical features of the lesion and life expectancy of the patients. Several large-scale randomized clinical trials comparing CEA and CAS have shown that periprocedural stroke was more frequent in CAS (especially in symptomatic patients), while myocardial infarction was more often seen in CEA., ${ }^{5,6}$ CAS is a potentially less invasive procedure compared to CEA, with a low risk of cranial nerve injury, wound complications and neck haematoma, but it is vulnerable to endovascular access complications. Endovascular treatment methods including CAS are used more widely nowadays due to increasing age and comorbid conditions of the patients with carotid artery stenosis. The aim of this study was to evaluate the clinical, demographic and procedural features of the patients who underwent CAS performed by interventional cardiologists in a single-center.

\section{MATERIAL and METHODS}

A total of 86 patients who underwent CAS between Janu- ary 2019 and December 2019 were enrolled in this retrospective, descriptive, cross-sectional study. ICA stenosis was confirmed with noninvasive tests, such as doppler ultrasonography, computed tomography or magnetic resonance angiography before the procedure. Initially, selective carotid angiography was performed to assess the severity of stenosis in the internal carotid artery. The percentage of ICA stenosis was calculated by angiography according to the North American Symptomatic Carotid endarterectomy Trial (NASCET) criteria and CAS procedure was performed in suitable patients according to the current guidelines. ${ }^{4,7}$ All of the patients underwent a neurological examination before and after the procedure. Demographic and clinical features, perioperative and in-hospital outcomes were retrospectively analyzed from the database by the investigators. The study was approved by Local Ethics Committee (University of Sakarya, School of Medicine, Ethics Committee; date: 19.11.2020 number: $71522473 / 050.01 .04 / 605)$ and written informed consent was obtained from all patients before the procedure. The study was conducted according to the principles of the Declaration of Helsinki.

The patients were treated with acetylsalicylic acid $300 \mathrm{mg}$ and clopidogrel $600 \mathrm{mg}$ before stenting. Dual antiplatelet therapy with $100 \mathrm{mg}$ acetylsalicylic acid daily and either $75 \mathrm{mg}$ clopidogrel daily was prescribed for one month. All of the procedures were performed under local anesthesia through right femoral artery. After inserting 8-F introducer sheath into common femoral artery, selective imaging of each carotid arteries was performed by using 5-F Simmons-2 cathater. 100IU/kg dose of intravenous heparin was administered to achieve an activated clotting time of 250-300 seconds. Proximal (MoMA, Invatec S.p.A., Roncadelle, Italy) or distal protection (Emboshield NAV6, Abbott Vascular, Inc., Santa Clara, CA, USA) devices were used in all patients. $0.5-1 \mathrm{mg}$ of atropine was used routinely to prevent hypotension and bradycardia before predilatation. Closed-cell stents (Xact, Abbott Vascular, Inc., Santa Clara, CA, USA) or open-cell stents (Protégé Rx, Medtro- 
nic Inc., Minneapolis, MN, USA) were used depending on operator's preference. Residual stenosis $<30 \%$ was defined as optimal range opening. Post-dilatation with various size of balloons was performed in patients with residual stenosis. After viewing final angiograms of the internal carotid artery and intracranial arteries, the protection devices were retrieved and the arterial introducer was removed. Manual compression was applied to achieve hemostasis. Patients were discharged after 24 hours of follow-up.

\section{Statistical Analysis}

Statistical analyses were performed using statistical software (SPSS 20.0, Chicago, IL, USA). Parameters were expressed as mean $\pm \mathrm{SD}$ in normal distribution. The chi-square and the Student's t-test were used for categorical and continuous variables, respectively. Fisher's exact test was applied in analyzing small samples. For continuous variables, differences between the two groups were evaluated using the Student's t-test when data were normally distributed. A p-value less than 0.05 was considered statistically significant.

\section{RESULTS}

A single-center retrospective analysis was made of the data of 86 patients (62 males/24 females; mean age: 67.7 \pm 9.3 years) with carotid artery stenosis and hospitalized for CAS between January 2019 and December 2019 at a single institution. Among these patients, 46 of the patients (53.5\%) were symptomatic because of a history of transient ischemic attack (TIA) or stroke in the preceding 6 months, and the remain of the patients were asymptomatic (40 patients, $46.5 \%$ ). 35 patients (40.7\%) had diabetes mellitus, 73 patients $(84.9 \%)$ had a history of hypertension, 27 patients (31.4\%) had previous coronary artery disease, 52 patients $(60.5 \%)$ had hyperlipidemia. The baseline characteristics of the patients are summarized in Table 1. The mean age of the patients was significantly lower in symptomatic group compared to asymptomatic group $(65.5 \pm 10.7$ vs $70.2 \pm 6.8, \mathrm{p}=0.019$ ) (Table 3 ). The other characteristics were similar between the two groups (Table 3 ).
Table 1. Characteristics of the patients underwent carotid artery stenting

\begin{tabular}{|l|l|}
\hline Number of patients & 86 \\
\hline Age (years \pm SD) & $67.7 \pm 9.3$ \\
\hline Female Gender (n,\%) & $24(27.9)$ \\
\hline Hypertension $(\mathrm{n}, \%)$ & $73(84.9)$ \\
\hline Diabetes Mellitus (n,\%) & $35(40.7)$ \\
\hline Coronary artery disease (n,\%) & $27(31.4)$ \\
\hline Hyperlipidemia (n,\%) & $52(60.5)$ \\
\hline Smoking habitus (n,\%) & $20(23.3)$ \\
\hline Congestive heart failure (n,\%) & $9(10.5)$ \\
\hline Chronic kidney disease $(\mathrm{n}, \%)$ & $4(4.7)$ \\
\hline
\end{tabular}

Table 2. Features of carotid lesions and procedural characteristics of the patients

\begin{tabular}{|c|c|}
\hline Symptomatic (n,\%) & $30(24.4)$ \\
\hline \multicolumn{2}{|l|}{ Plaque characteristic } \\
\hline Fibro-fatty $(\mathrm{n}, \%)$ & $26(30.2)$ \\
\hline Calcific $(n, \%)$ & $21(24.4)$ \\
\hline Mixed (n,\%) & $39(45.3)$ \\
\hline \multicolumn{2}{|l|}{ Localization } \\
\hline Right ICA (n,\%) & $42(48.8)$ \\
\hline Left ICA $(n, \%)$ & $44(51.2)$ \\
\hline \multicolumn{2}{|l|}{ Lesion severity } \\
\hline$<70 \%(\mathrm{n}, \%)$ & $4(4.6)$ \\
\hline $70-90 \%(\mathrm{n}, \%)$ & $38(44.1)$ \\
\hline$>90 \%(\mathrm{n}, \%)$ & $44(51.2)$ \\
\hline \multicolumn{2}{|l|}{ Emboli protection } \\
\hline Distal (n,\%) & $84(97.6)$ \\
\hline Proximal $(\mathrm{n}, \%)$ & $2(2.3)$ \\
\hline Predilatation (n,\%) & $79(91.9)$ \\
\hline Postdilatation (n,\%) & $7(8.1)$ \\
\hline Pre- \& postdilatation $(\mathrm{n}, \%)$ & $4(4.7)$ \\
\hline \multicolumn{2}{|l|}{ Stent size } \\
\hline 6-8 mm $(n, \%)$ & $35(40.7)$ \\
\hline 7-10 mm (n,\%) & $51(59.3)$ \\
\hline Complication (stroke/TIA) $(\mathrm{n}, \%)$ & $2(2.3)$ \\
\hline
\end{tabular}


Table 3. Clinical and procedural features comparing symptomatic and asymptomatic patients.

\begin{tabular}{|l|c|c|c|}
\hline & $\begin{array}{c}\text { Symptomatic } \\
(\mathbf{n}=\mathbf{4 6})\end{array}$ & $\begin{array}{c}\text { Asymptomatic } \\
(\mathbf{n = 4 0 )}\end{array}$ & $\begin{array}{c}\mathbf{P} \\
\text { value }\end{array}$ \\
\hline Age (years \pm SD) & $65.5 \pm 10.7$ & $70.2 \pm 6.8$ & 0.019 \\
\hline
\end{tabular}

Plaque characteristic

\begin{tabular}{|l|c|c|c|}
\hline Fibro-fatty (n,\%) & $18(39.1)$ & $8(20)$ & 0.126 \\
\hline Calcific (n,\%) & $11(23.9)$ & $10(25)$ & \\
\hline Mixed (n,\%) & $17(37)$ & $22(55)$ & \\
\hline
\end{tabular}

Localization

\begin{tabular}{|l|c|c|c|}
\hline Right $(\mathrm{n}, \%)$ & $24(52.2)$ & $20(50)$ & 0.841 \\
\hline Left $(\mathrm{n}, \%)$ & $22(47.8)$ & $20(50)$ & \\
\hline \multicolumn{4}{|l|}{ EPD } \\
\hline Proximal (n,\%) & $1(2.2)$ & $1(2.5)$ & 1.000 \\
\hline Distal (n,\%) & $45(97.8)$ & $39(97.5)$ & \\
\hline TIA/Stroke (n,\%) & $3(6.5)$ & $0(0)$ & 0.245 \\
\hline
\end{tabular}

EPD: embolic protection device, TIA: transient ischemic attack.

Predilatation was performed in 79 patients (91.9\%). In 7 patients $(8.1 \%)$ postdilatation was required due to insufficient opening. Only in 4 patient, both predilatation and postdilatation was performed during the procedure. In most of the patients (84 patients, 97.7\%) distal embolic protection device (EPD) were used. Only in two patients (2.3\%) proximal EPD were used. Technical success rate was $98.8 \%$ (85/86) in our study. In-hospital death and disabling stroke was not observed in any patients. TIA was observed in two patients. In one of them right-sided hemiparesis was developed approximately half an hour after the procedure, the control angiogram showed stent recoil in the left ICA. Angioplasty by a larger size balloon and another stent deployment provided optimal opening. The symptoms of the patient was recovered after the procedure and the patient was discharged uneventfully. The procedural features are shown in Table 2.

\section{DISCUSSION}

In this present study, 86 patients who underwent CAS over one-year period evaluated retrospectively. Our results revealed a $98.8 \%$ technical success rate and a $2.3 \%$ TIA complication rate. Stroke or in-hospital death was not observed. The current guidelines state that the complication rates should be less than $3 \%$ for asymptomatic patients and $6 \%$ for symptomatic patients in order to perform CAS. Karaduman et al. reported that in the study involving 145 patients who underwent CAS, no death was recorded in hospital follow-up, however, TIA or stroke was observed in 5 patients (3.4\%). 8 Karaduman et al. also reported that all these 5 patients had been treated due to symptomatic carotid artery stenosis, and TIA or stroke was not observed in asymptomatic patients. The results of our study seem to be consistent with the complication rates recommended in the guidelines and previous studies in our country.

CAS has been proposed as an alternative therapeutic option to CEA in selected patients. Randomized controlled trials have shown that the incidence of ipsilateral strokes was more often in CAS procedures especially in symptomatic patients, while myocardial infarction during CEA procedure was more frequently seen. ${ }^{9,10}$ In addition to this, silent ischemic lesions are more commonly detected after CAS compared to CEA. ${ }^{5,6}$ EPDs significantly decreases cerebral embolism during CAS procedure, however, the incidence of cerebral microembolism after CAS still remains high compared to CEA. ${ }^{11,12}$

Most of the patients in our study had one or more comorbid diseases. The most common concomittant comorbid disease was hypertension. Approximately three quarters of the patients had hypertension, while one third had diabetes mellitus. One-third of the patients had a history of coronary artery disease. The atherosclerotic plaque structure was commonly calcific or mixed type in the elderly, while fibro-fatty plaques were more common in young patients. Fibro-fatty plaques were more common in symptomatic patients, however, there was no significant difference 
between symptomatic and asymptomatic groups.

The use of EPDs are the most important part of the carotid stenting to prevent thromboembolism of carotid plaque particles during procedure. Current guidelines suggest that an EPD should be considered in patients undergoing CAS. ${ }^{4}$ In our study, an EPD was used in all patients during the procedure. Previous studies showed that proximal balloon occlusion devices are more effective than filter protection in reducing cerebral microembolism. ${ }^{13,14}$ However, proximal EPD devices are not used frequently due to the difficulties of usage in clinical practice. The distal EPD was used in most of the patients in our study depending on operator choice.

There are a number of limitations to this study. The main limitations of our study are the retrospective design and relatively small number of the patients. In addition, CAS was performed by different operators, which can affect the complication rates of the procedures. Brain magnetic resonance imaging was not performed routinely after the procedure, therefore silent ischemia due to the procedure was not evaluated.

In conclusion, CAS is safe and effective treatment method in carotid artery stenosis with low complication rates in experienced centers. CAS is alternative treatment to CEA especially in patients with high surgical risk. Experience of the operators, selection of appropriate patients, use of EPDs and close follow-up during and after the procedure are important for achieving high success and low complication rates.

The study was approved by University of Sakarya, School of Medicine, Ethics Committee; date: 19.11.2020 number: 71522473/050.01.04/605. 
Sakarya Med J 2021;11(4):737-742

KOCAYİĞíT et al., : Carotid Artery Stenting

\section{Kaynaklar}

1. Mozaffarian D, Benjamin EJ, Go AS, Arnett DK, Blaha MJ, Cushman M, et al. American Heart Association Statistics Committee; Stroke Statistics Subcommittee. Heart Disease and Stroke Statistics-2016 Update: A Report From the American Heart Association. Circulation 2016;133(4):e38-360.

2. Powers WJ, Rabinstein AA, Ackerson T, Adeoye OM, Bambakidis NC, Becker K et al. American Heart Association Stroke Council. 2018 Guidelines for the Early Management of Patients With Acute Ischemic Stroke: A Guideline for Healthcare Professionals From the American Heart Association/American Stroke Association. Stroke 2018;49(3):e46-e110

3. Cremonesi A, Castriota F, Secco GG, Macdonald S, Roffi M. Carotid artery stenting: an update. Eur Heart J 2015; 36: 13-21.

4. Aboyans V, Ricco JB, Bartelink MEL, Björck M, Brodmann M, Cohnert T, et al; ESC Scientific Document Group. 2017 ESC Guidelines on the Diagnosis and Treatment of Peripheral Arterial Diseases, in collaboration with the European Society for Vascular Surgery (ESVS): Document covering atherosclerotic disease of extracranial carotid and vertebral, mesenteric, renal, upper and lower extremity arteriesEndorsed by: the European Stroke Organization (ESO)The Task Force for the Diagnosis and Treatment of Peripheral Arterial Diseases of the European Society of Cardiology (ESC) and of the European Society for Vascular Surgery (ESVS). Eur Heart J 2018;39:763-816.

5. Bonati LH, Jongen LM, Haller S, Flach HZ, Dobson J, Nederkoorn PJ, et al; ICSS-MRI study group. New ischaemic brain lesions on MRI after stenting or endarterectomy for sympto matic carotid stenosis: a substudy of the International Carotid Stenting Study (ICSS). Lancet Neurol 2010;9:353-62.

6. Kuliha M, Roubec M, Procházka V, Jonszta T, Hrbáć T, Havelka J, et al. Randomized clinical trial comparing neurological outcomes after carotid endarterectomy or stenting. Br J Surg 2015;102:194-201.

7. Ferguson GG, Eliasziw M, Barr HW, Clagett GP, Barnes RW, Wallace MC, et al. The North American Symptomatic Carotid Endarterectomy Trial: surgical results in 1415 patients. Stroke 1999; 30: 1751-8.
8. Karaduman BD, Ayhan H, Keleș T, Bozkurt E. Efficacy and safety of carotid artery stenting: Experience of a single center. Turk Kardiyol Dern Ars. 2020 Oct;48(7):646-655.

9. Eckstein HH, Reiff T, Ringleb P, Jansen O, Mansmann U, Hacke W; SPACE 2 Investigators. SPACE-2: A Missed Opportunity to Compare Carotid Endarterectomy, Carotid Stenting, and Best Medical Treatment in Patients with Asymptomatic Carotid Stenoses. Eur J Vasc Endovasc Surg 2016;51:761-5.

10. Mas JL, Trinquart L, Leys D, Albucher JF, Rousseau H, Viguier A, et al; EVA-3S investigators. Endarterectomy Versus Angioplasty in Patients with Symptomatic Severe Carotid Stenosis (EVA-3S) trial: results up to 4 years from a randomised, multicentre trial. Lancet Neurol 2008;7:885-92.

11. Roh HG, Byun HS, Ryoo JW, Na DG, Moon WJ, Lee BB, et al. Prospective analysis of cerebral infarction after carotid endarterectomy and carotid artery stent placement by using diffusion weighted imaging. AJNR Am J Neuroradiol 2005;26:376-84.

12. Maleux G, Demaerel P, Verbeken E, S Daenens, F Heye, A Van Sonhoven, et al. Cerebral ischemia after filter-protected carotid artery stenting is common and cannot be predicted by the presence of substantial amount of debris captured by the filter device. AJNR Am J Neuroradiol 2006;27:1830-3.

13. Bijuklic K, Wandler A, Hazizi F, Schofer J. The PROFI study (Prevention of Cerebral Embolization by Proximal Balloon Occlusion Compared to Filter Protection During Carotid Artery Stenting): a prospective randomized trial. J Am Coll Cardiol 2012;59:1383-9.

14. Schmidt A, Diederich KW, Scheinert S, Bräunlich S, Olenburger T, Biamino G, et al. Effect of two different neuroprotection systems on microembolization during carotid artery stenting. $J$ Am Coll Cardiol 2004;44:1966-9. 